\title{
Effects of water temperature, salinity and feeding regimes on metamorphosis, growth and otolith Sr:Ca ratios of Megalops cyprinoides leptocephali
}

\author{
Hui-Lun Chen ${ }^{1}$, Kang-Ning Shen ${ }^{1}$, Chih-Wei Chang ${ }^{3,4}$, Yoshiyuki Iizuka ${ }^{5}$, \\ Wann-Nian Tzeng ${ }^{1,2, *}$
}

\footnotetext{
${ }^{1}$ Institute of Fisheries Science, and ${ }^{2}$ Department of Life Science, National Taiwan University, Taipei, Taiwan 106, ROC ${ }^{3}$ National Museum of Marine Biology and Aquarium, Pingtung, Taiwan 944, ROC

${ }^{4}$ Institute of Marine Biodiversity and Evolution, National Donghwa University, Hualien, Taiwan 974, ROC

${ }^{5}$ Institute of Earth Sciences, Academia Sinica, Nankang, Taipei, Taiwan 115, ROC National Taiwan University, Taipei, Taiwan 106, ROC
}

\begin{abstract}
We examined the effects of water temperature, salinity and feeding regime on leptocephalus metamorphosis, and on daily growth increment deposition and strontium:calcium (Sr:Ca) ratios of otoliths in the Pacific tarpon Megalops cyprinoides. The tarpons at the pre-metamorphic leptocephalus stage (SI) were collected in the estuary, marked with tetracycline and then reared for 18 and $30 \mathrm{~d}$ in 2 independent experiments with different temperatures $\left(20,25\right.$ and $\left.30^{\circ} \mathrm{C}\right)$, salinities $(0,10$ and 35) and feeding regimes (fed and starved) - environmental conditions that the fish may experience in the wild. Temporal changes in $\mathrm{Sr}$ :Ca ratios from the primordium to the otolith edge of the reared tarpon were examined with an electron probe microanalyzer. At the optimal temperature $\left(25^{\circ} \mathrm{C}\right)$ in Expt I, the leptocephalus completed metamorphosis (SII and SIII) after ca. 2 wk irrespective of being fed or starved and reared in low (10) or high (35) salinity, although both somatic and otolith growth rates were lower in starved than in fed groups. However, in Expt II, metamorphosis was delayed at SII when the larvae were reared close to winter water temperature $\left(20^{\circ} \mathrm{C}\right)$, and the duration of metamorphosis was reduced to less than $12 \mathrm{~d}$ when the leptocephalus was reared at $30^{\circ} \mathrm{C}$. This indicated that the rate of metamorphosis was significantly influenced by water temperature. Meanwhile, the drastic change in Sr:Ca ratios and increment width in the otolith of the leptocephalus during metamorphosis was also significantly different among different temperatures, salinities and feeding regimes in different degrees. The present study indicated that these factors significantly influenced the metamorphosis rate of the leptocephalus and subsequently their daily growth increment deposition and $\mathrm{Sr}$ :Ca ratios in otolith.
\end{abstract}

KEY WORDS: Pacific tarpon $\cdot$ Megalops cyprinoides $\cdot$ Metamorphosis $\cdot$ Otolith Strontium:Calcium ratios $\cdot$ Daily growth increments $\cdot$ Environmental factors

\section{INTRODUCTION}

Otoliths are located in the inner ear of fish and aid in hearing and balance. It is usually rhythmically deposited on a daily basis and thus produces daily growth increments (Pannella 1971) that allow us to determine the ages of larval fish in early life history. Otoliths are bio-mineralized crystals composed mainly of $\mathrm{CaCO}_{3}$ with a minor organic matrix (Degens et al.
1969). It was found that at least 31 elements are deposited in the growth increments of fish otoliths (Campana 1999). Otoliths are metabolically inert, and once an element is deposited in the otolith it will not be re-absorbed like other hard structures (scale and bone) (Campana \& Neilson 1985). The deposition of the elements in the otolith is a biologically controlled process that reflects ambient elemental concentrations and environmental conditions (Secor et al. 1995, Farrell \& 
Campana 1996). The concentrations of strontium (Sr) and calcium (Ca) are ca. 100 and 4.5 times higher in seawater than in freshwater, respectively (Campana 1999). The Sr:Ca ratio in otolith is positively correlated to that in the ambient waters (Tzeng 1996). Based on these characteristics, otolith microchemistry, such as $\mathrm{Sr}$ :Ca ratio, has been widely used to reconstruct past life-history events of fish and migratory behavior and habitat usage for conservation and management purposes (e.g. Tsukamoto \& Arai 2001, Tzeng et al. 2003). In addition, the physiology and ontogeny (Kalish 1989, Sadovy \& Severin 1992, Tzeng 1996) and even the otolith crystal structure itself (Melancon et al. 2005, Tzeng et al. 2007) all have the potential to influence $\mathrm{Sr}$ :Ca ratios in fish otoliths. Thus, it is important to understand changes in the mechanisms of otolith microchemistry before it is used to study the environmental history of fish.

A drastic decrease in otolith $\mathrm{Sr}$ :Ca ratios occurs in the early stage of fishes with leptocephalus larvae such as anguillid eels Anguilla spp. (Tzeng et al. 2002, Jessop et al. 2006), conger eels Conger myriaster, $C$. conger and C. oceanicus (Otake et al. 1997, Correia et al. 2003, 2004), moray eel Gymnothorax reticularis and pike eel Muranenesox cinereus (Ling et al. 2005). The drastic decrease of $\mathrm{Sr}: \mathrm{Ca}$ ratios in otolith was assumed -in the case of the marine conger eel C. myriaster - to be related to leptocephalus metamorphosis, through the degradation of glycosaminoglycans (GAGs) in the leptocephalus body (Otake et al. 1997), and - in the case of the catadromous eel - to the salinity gradient when the leptocephali metamorphose into glass eels during migration from offshore to estuary (Tzeng 1996). However, there are no direct observations to prove this assumption, which is based on extrapolation of the data observed from the premetamorphic leptocephalus larva and the post-metamorphic glass eel (Otake et al. 1994, 1997, Tzeng 1996). The availability of anguillid eel leptocephali for validation experiments is limited because the artificial propagation of these eels is still difficult. Fortunately, the leptocephalus of Pacific tarpon Megalops cyprinoides can be reared in aquariums until it metamorphoses to the juvenile stage and is available for conducting direct observation experiments (Chen \& Tzeng 2006). The tarpon is a member of the Superorder of Elopomorpha, which includes Elopiformes, Anguilliformes, Albuliformes and Sacco- pharyngiformes (Tsukamoto \& Okiyama 1997). The members of Elopomorpha all have willow-leaf-shaped larva (leptocephalus) and undergo drastic changes in morphology (such as total length, body shape and position of internal organs) during metamorphosis (Forey et al. 1996). Unlike anguillid eel that spawn in the open ocean (Tsukamoto 1992), the Pacific tarpon is thought to spawn near the coast, with leptocephali subsequently drifting with tidal currents and metamorphosing into juveniles in estuaries (Tzeng \& Yu 1986). Thus, it is easier to collect and rear the leptocephalus of the tarpon than that of the anguillid eels (Chen \& Tzeng 2006).

The present study examined the temporal changes in daily growth increments and $\mathrm{Sr}: \mathrm{Ca}$ ratios in the otoliths of reared tarpon during metamorphosis from leptocephalus to juvenile stages, to understand the effects of environmental temperature, salinity and feeding regimes on metamorphosis rate, otolith growth and Sr:Ca ratios. The Sr:Ca ratios in otolith were analyzed by electron probe microanalyzer, and the age was determined by counting the daily growth increments. A possible mechanism is given for the drastic changes in otolith Sr:Ca ratios during metamorphosis.

\section{MATERIALS AND METHODS}

Experimental design. Pre-metamorphic leptocephali of Pacific tarpon were collected on 15 to 17 June 2003 using an anchored bag net set against the tidal current in the estuary of Gong-Shy-Tyan Creek (25 $15^{\circ}$ ' 22" N, $\left.121^{\circ} 25^{\prime} 13^{\prime \prime} \mathrm{E}\right)$, a tributary of the Tanshui River in northern Taiwan (Fig. 1). After acclimation at a salinity

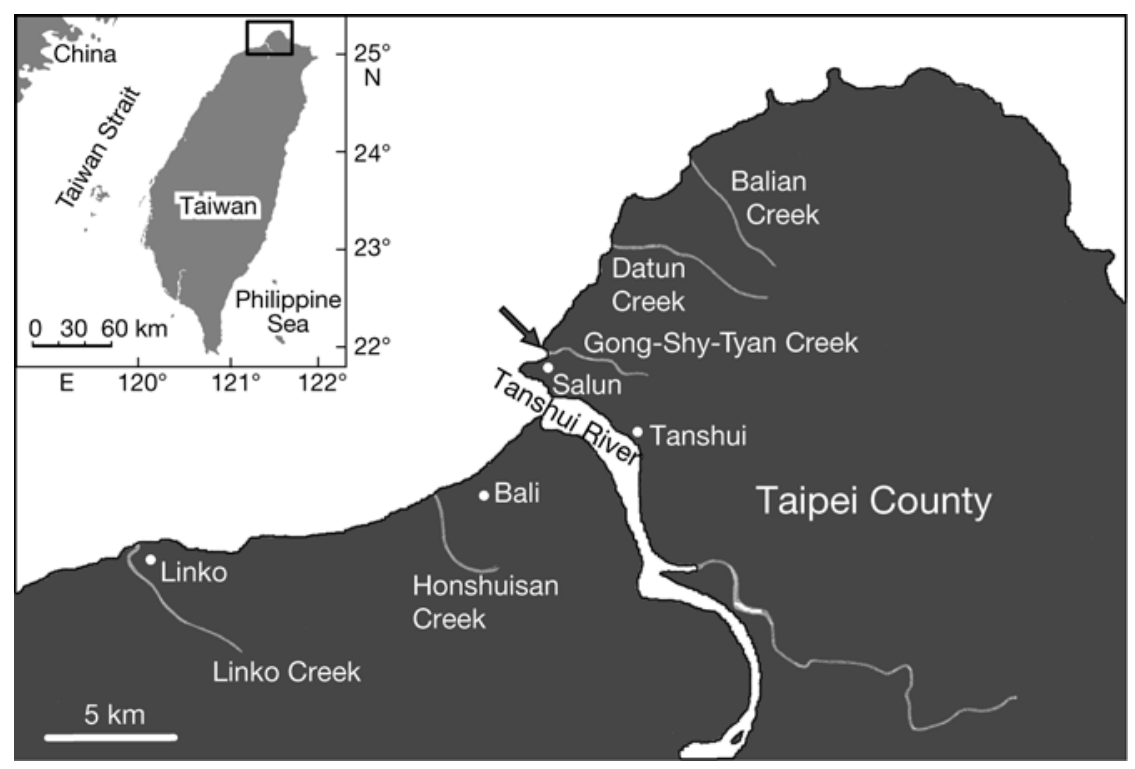

Fig. 1. Sampling site at estuary of Gong-Shy-Tyan Creek (arrow) 
of 15 psu for $1 \mathrm{~d}$, healthy leptocephali were immersed in tetracycline (TC) solution with a concentration of $350 \mathrm{mg} \mathrm{l}^{-1}$ for $24 \mathrm{~h}$ to mark the otoliths with a fluorescent band at the onset of the experiment. Two rearing experiments with different combinations of temperatures, salinities and feeding regimes were conducted to examine the temporal changes in the otolith $\mathrm{Sr}: \mathrm{Ca}$ ratio of the tarpon during its metamorphosis from leptocephalus to the juvenile stage in relation to ontogenetic shift and also its effect on otolith growth. The development of the Pacific tarpon leptocephalus was classified into 3 sub-stages according to the changes in external morphology, fish length, otolith increment width (OIW) and Sr:Ca ratios (Chen \& Tzeng 2006). Stage I (SI) is the pre-metamorphic leptocephalus larvae with relatively consistent OIWs and otolith $\mathrm{Sr}: \mathrm{Ca}$ ratios. Stage II (SII) is the period initiated when the fish lengths and otolith $\mathrm{Sr}$ :Ca ratios decrease with an accompanying increase in OIWs. Stage III (SIII) is when the shrunk larvae resume increasing body length until termination of metamorphosis at the beginning of the juvenile stage. The OIWs reached a peak value at the end of SII, while the otolith Sr:Ca ratios decreased at the beginning of SII. From these changes in OIW and Sr:Ca ratios, the duration of the metamorphosis and the stages of the leptocephalus can be objectively characterized. The leptocephali of Pacific tarpon collected during recruitment in the estuary were all SI larvae with a mean $( \pm \mathrm{SD})$ total length of $28.0 \pm 0.86 \mathrm{~mm}$ (n = 13).

Expt I: salinity and feeding effects: A total of 120 TCmarked leptocephali were randomly distributed to 4 groups with different combinations of salinities (10 and $35 \mathrm{psu}$ ) and feeding regimes (fully fed and starved). Each group was reared in a $20 \mathrm{l}$ aquarium at a constant water temperature of $25^{\circ} \mathrm{C}$ with a photoperiod of $10 \mathrm{~h}$ light:14 h dark cycle similar to that in the estuary when the leptocephali were collected. The full feeding group was fed daily with a fixed quantity of newly hatched brine shrimp nauplii Artemia spp. The salinities simulated the salinity range in the estuary during flood and ebb tides. The starved group was included because half of the larvae and juveniles in the wild were found to be starved even if food was generally considered to be plentiful in the estuary (Tzeng \& Yu 1992). Total lengths of the leptocephali were measured immediately after they were sacrificed on Day 18. Most of the starved group did not survive until Day 18, so Expt I was stopped when all the starved fish died. The larval development, including organs, stomach contents, melanophores in fins and silvery abdomen was defined as in a previous study (Chen \& Tzeng 2006).

Expt II: temperature and salinity effects: Expt II examined the effects of extreme environmental conditions on the larval metamorphosis; thus, another 180
TC-marked leptocephali were randomly distributed to 6 experimental groups with a combination of 2 temperatures $\left(20\right.$ and $30^{\circ} \mathrm{C}$ ) and 3 salinities $(0,10$ and $35 \mathrm{psu})$. The temperatures 20 and $30^{\circ} \mathrm{C}$ simulated winter and summer water temperatures in the estuary. The salinity range simulated the freshwater discharge of the river during the rainy season and the influx of highsalinity seawater during high tide. The rearing density, photoperiod and feeding quantity were all similar to those in Expt I. Six individuals were sacrificed weekly for length measurement throughout the month-long experimental period.

\section{Otolith preparation for $\mathrm{Sr}$ :Ca ratios analyses and age determination}

The sagittae, largest of the 3 pairs of fish otoliths, were removed and mounted with epoxy resin (Epofix, Struers). Then the otoliths were polished using a Metaserv grinder-polisher (Buehler) equipped with various grit sandpapers and a polishing cloth with $0.05 \mu \mathrm{m}$ alumina slurry until the primordium was revealed. After coating the otolith surface with carbon, $\mathrm{Sr}$ and $\mathrm{Ca}$, concentrations were measured from the primordium to the otolith edge by an Electron Probe MicroAnalyzer (EPMA, JXA-8900R, JEOL) with an electron beam size of $5 \times 4 \mathrm{\mu m}^{2}$. The accelerating voltage and probe current of the beam condition were set at $15 \mathrm{kV}$ and $3 \mathrm{nA}$. Strontianite $\left(\left[\mathrm{Sr}_{0.95} \mathrm{Ca}_{0.05}\right] \mathrm{CO}_{3}\right)$ and aragonite $\left(\mathrm{CaCO}_{3}\right)$ were used as standards to calibrate the concentration of $\mathrm{Sr}$ and $\mathrm{Ca}$ in the otolith. Then the temporal change of the $\mathrm{Sr}$ :Ca ratios in the experimental fish otoliths was determined.

After EPMA, the otoliths were repolished to remove the carbon coating and etched with $0.05 \mathrm{M} \mathrm{HCl}$ for $10 \mathrm{~s}$ to $1 \mathrm{~min}$ to enhance the contrast of the daily growth increments. The daily growth increments were counted to determine the daily age of the fish. The OIWs were measured from the primordium to the TC mark and otolith edge, along the maximum radius of the anteriorposterior axis, using a transmitted light microscope at $400 \times$ magnification to determine the otolith growth rate. The TC mark in the otolith was examined using a fluorescence microscope under incident ultraviolet light with a band-pass filter of 400 to $440 \mathrm{~nm}$ and a long-pass barrier filter of $470 \mathrm{~nm}$ to determine the start of the experimental treatments (Chen \& Tzeng 2006).

\section{Data analysis}

The differences in mean total lengths and otolith radii and $\mathrm{Sr}$ :Ca ratios among different groups at SIII in Expt I were tested by 2-way analysis of variance 
(ANOVA), while the changes in OIWs and Sr:Ca ratios with fish growth among different groups at SII in Expts I and II and the OIWs at SIII in Expt I were tested by 2way analysis of covariance (ANCOVA). On the other hand, the changes in OIWs with fish growth among different salinities at SIII in Expt II were tested by oneway ANCOVA, while the mean $\mathrm{Sr}$ :Ca ratios of the fish among different salinities at SIII and the juvenile stage, and the mean OIWs among different salinities in the juvenile stage, were tested by one-way ANOVA. Furthermore, the differences among groups were ranked with the Tukey HSD multiple range test at a significance level of $\alpha=0.05$. Shrinkage in mean total lengths, by salinity group, between 20 and $30^{\circ} \mathrm{C}$ in Expt II were tested by $t$-test.

\section{RESULTS}

\section{Effects of salinity and feeding (Expt I)}

After $18 \mathrm{~d}$ of rearing at $25^{\circ} \mathrm{C}$, the leptocephali developed from the pre-metamorphic SI into the completely metamorphic SIII irrespective of being reared at salinities 10 and $35 \mathrm{psu}$. The development rate was slower in starved than in fed larva. The fed larvae had welldeveloped organs, full stomach contents, concentrated melanophores in fins and silvery abdomens.

The effects of different salinity and feeding regimes on fish lengths were all significant (both $p<0.001$ ), but only feeding regimes had an effect on otolith radii $(\mathrm{p}<$ 0.001). No significant interactive effects were found between salinities and feeding regimes (fish lengths, $\mathrm{p}=0.98$ and otolith radii, $\mathrm{p}=0.88$ ). At the end of $18 \mathrm{~d}$ rearing, fed fish were longer (10 psu: $20.4 \pm 1.0 \mathrm{~mm}$, $35 \mathrm{psu}: 19.3 \pm 1.1 \mathrm{~mm}$ ) than starved groups (10 psu: $18.1 \pm 0.8 \mathrm{~mm}, 35 \mathrm{psu}: 17.1 \pm 0.9 \mathrm{~mm})$. The fed leptocephali grew faster in 10 psu than in 35 psu (Fig. 2a). Similarly, otolith radii after the TC mark were wider in fed (10 psu: $134.7 \pm 24.5 \mu \mathrm{m}, 35 \mathrm{psu}: 126.6 \pm 22.3 \mu \mathrm{m}$ ) than starved groups (10 psu: $79.2 \pm 24.2 \mu \mathrm{m}, 35 \mathrm{psu}$ : $68.9 \pm 13.1 \mu \mathrm{m}$ ) (Fig. 2b), but otolith radii did not differ significantly between 10 and 35 psu for fed or starved groups $(p=0.14)$.

The effects of salinity and feeding regimes on temporal changes of mean $( \pm \mathrm{SD})$ OIWs and $\mathrm{Sr}$ :Ca ratios in the otoliths of the experimental fish during the $18 \mathrm{~d}$ rearing period are shown in Fig. 3. The OIWs among groups before the TC mark, i.e. the leptocephalus at $\mathrm{SI}$, were narrow and relatively consistent, with an average of $2.12 \pm 0.38 \mu \mathrm{m}$. The OIWs increased dramatically to a maximum level at the end of SII and subsequently decreased in SIII to the level of SI, irrespective of rearing in salinities of 10 or $35 \mathrm{psu}$ (Fig. 3a,b). However, the mean OIWs in SII were
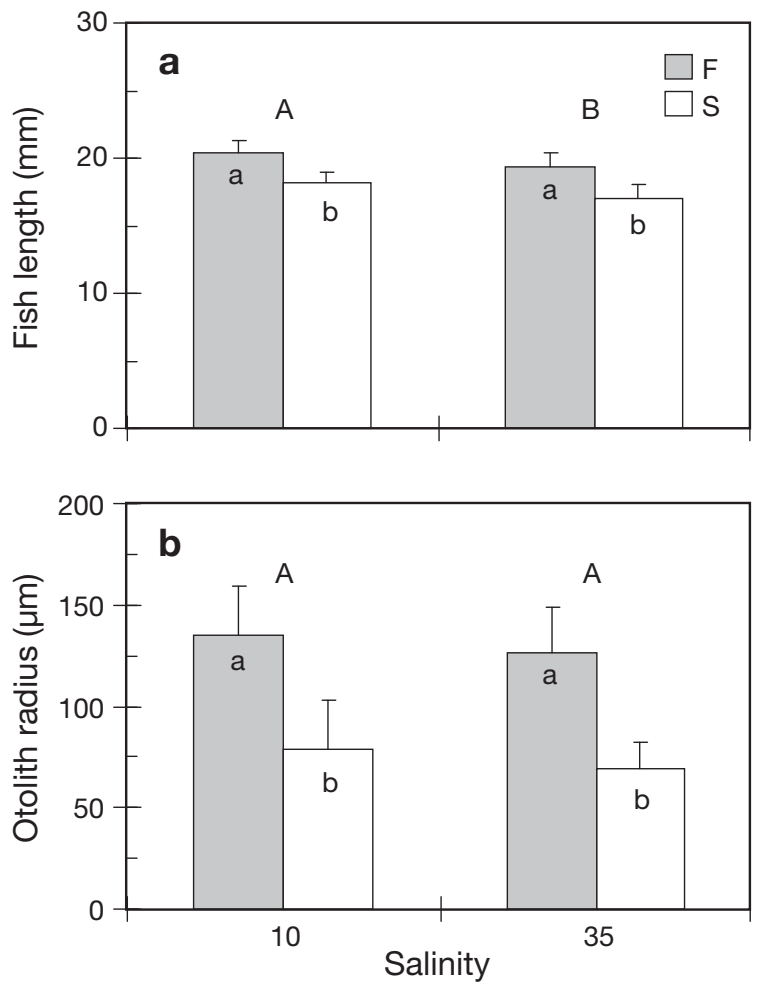

Fig. 2. Megalops cyprinoides. Comparison of mean $( \pm \mathrm{SD})(\mathrm{a})$ total length and (b) otolith radius of Pacific tarpon for fed (F) and starved (S) groups reared at salinities of 10 and 35 psu for $18 \mathrm{~d}$ after tetracycline (TC) marking. The radius was measured from the TC mark to the otolith edge. Different upperand lower-case letters indicate statistical difference in means (by 2-way ANOVA) between salinities and between feeding regimes, respectively

larger in fed $(12.6 \pm 5.1 \mu \mathrm{m}$ in $10 \mathrm{psu}$ and $13.3 \pm 4.6$ $\mu \mathrm{m}$ in $35 \mathrm{psu})$ than starved groups $(8.2 \pm 2.6 \mu \mathrm{m}$ in 10 psu and $7.5 \pm 2.0 \mu \mathrm{m}$ in $35 \mathrm{psu})(\mathrm{p}<0.001)$. Similarly, in SIII, OIWs were also larger in fed $(4.2 \pm 0.9 \mu \mathrm{m}$ in $10 \mathrm{psu}$ and $4.3 \pm 1.1 \mu \mathrm{m}$ in $35 \mathrm{psu}$ ) than starved groups $(3.1 \pm 1.8 \mu \mathrm{m}$ in $10 \mathrm{psu}$ and $2.3 \pm 1.1 \mu \mathrm{m}$ in $35 \mathrm{psu})(\mathrm{p}<0.001)$. No significant differences in OIW occurred between 10 and 35 psu for fed or starved groups in both SII $(p=0.70)$ and SIII $(p=0.59)$, and no interaction effect between feeding regime and salinity in both SII $(p=0.41)$ and SIII $(p=0.74)$ were observed. In contrast, the otolith $\mathrm{Sr}$ :Ca ratios were higher in SI $\left(9.29 \pm 0.26 \times 10^{-3}\right)$ but suddenly decreased in SII and maintained a constant level in SIII $\left(6.62 \pm 0.56 \times 10^{-3}\right)$, irrespective of salinity and feeding regime (Fig. 3c,d). However, both salinity and feeding regimes have a significant effect on $\mathrm{Sr}$ :Ca ratios in SII (feeding regimes $\mathrm{p}<0.01$, salinity $\mathrm{p}<0.001$, with no interaction effect between salinity and feeding regimes $p=0.87$ ) and in SIII (feeding regimes $\mathrm{p}<0.01$, salinity $\mathrm{p}<0.05$, but with interaction effect between salinities and feeding regimes $\mathrm{p}<0.05$ ). 

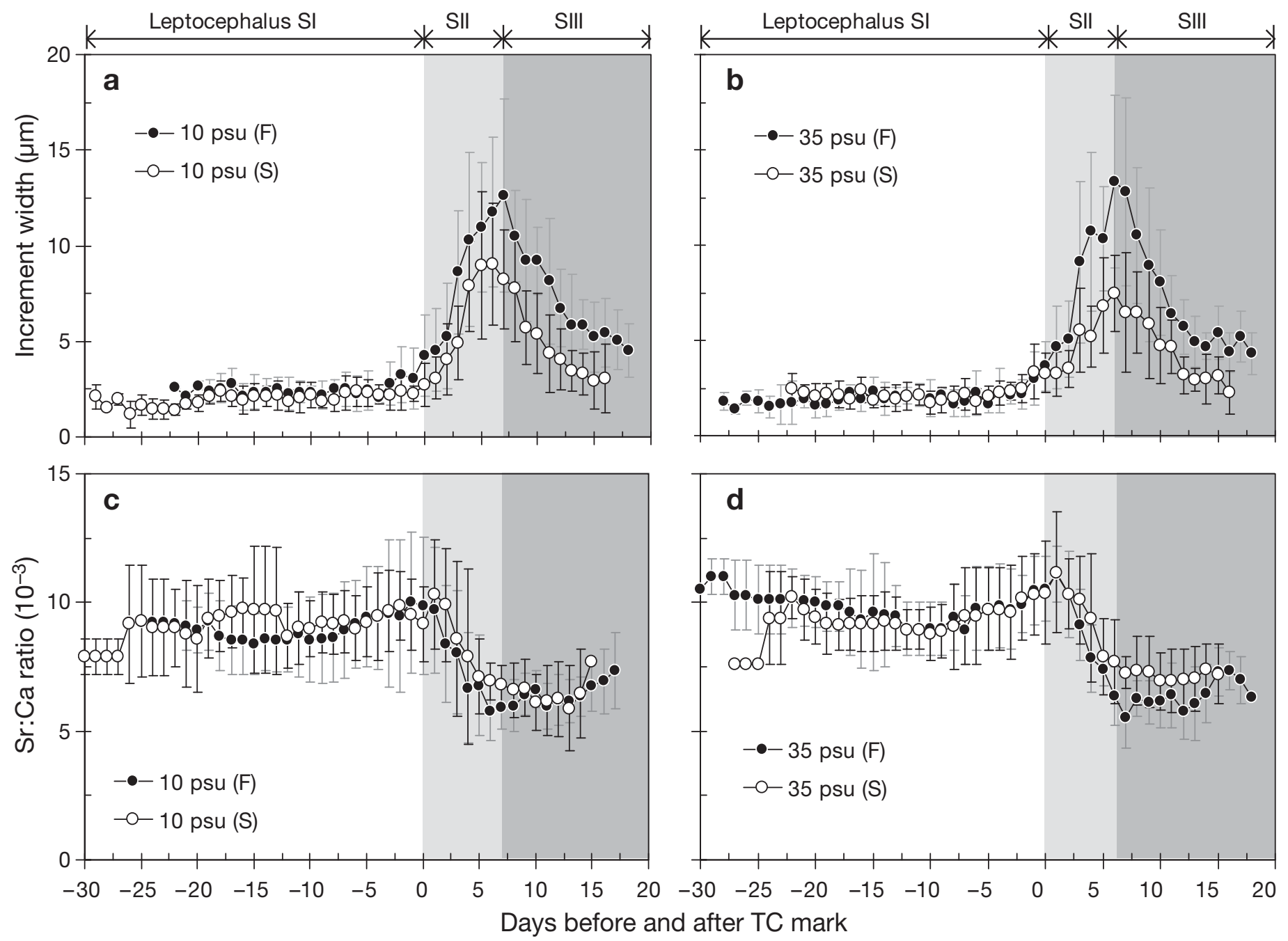

Fig. 3. Megalops cyprinoides. Temporal changes in mean $( \pm \mathrm{SD})(\mathrm{a}, \mathrm{b})$ increment width and $(\mathrm{c}, \mathrm{d})$ Sr:Ca ratios in the otoliths of Pacific tarpon during metamorphosis from SI to SIII, in relation to salinities (10 and $35 \mathrm{psu}$ ) and feeding regimes (F, fed; $\mathrm{S}$, starved)

\section{Effects of temperature and salinity (Expt II)}

The effect of temperature in delaying metamorphosis was shown in the comparison of the temporal changes in fish total lengths between the 20 and $30^{\circ} \mathrm{C}$ groups during the $28 \mathrm{~d}$ experimental period (Fig. 4). Mean total lengths of the fish at each of the subsequent dates of sacrifice were significantly smaller at $30^{\circ} \mathrm{C}$ than at $20^{\circ} \mathrm{C}$ ( $t=2.02$ to 9.17 , all $\mathrm{p}<0.001$ except day $28, \mathrm{p}<0.05)$. The smallest observed fish length during metamorphosis was $17.3 \mathrm{~mm}$ at Day 17 during the experiment at $30^{\circ} \mathrm{C}$.

At the end of the 1 mo rearing period, the experimental fish at $30^{\circ} \mathrm{C}$ had completely metamorphosed from the initial SI leptocephalus larvae to the juvenile stage irrespective of being reared in 0,10 or 35 psu, whereas at $20^{\circ} \mathrm{C}$ fish remained at SII and didn't develop to the advanced stages (Fig. 5).

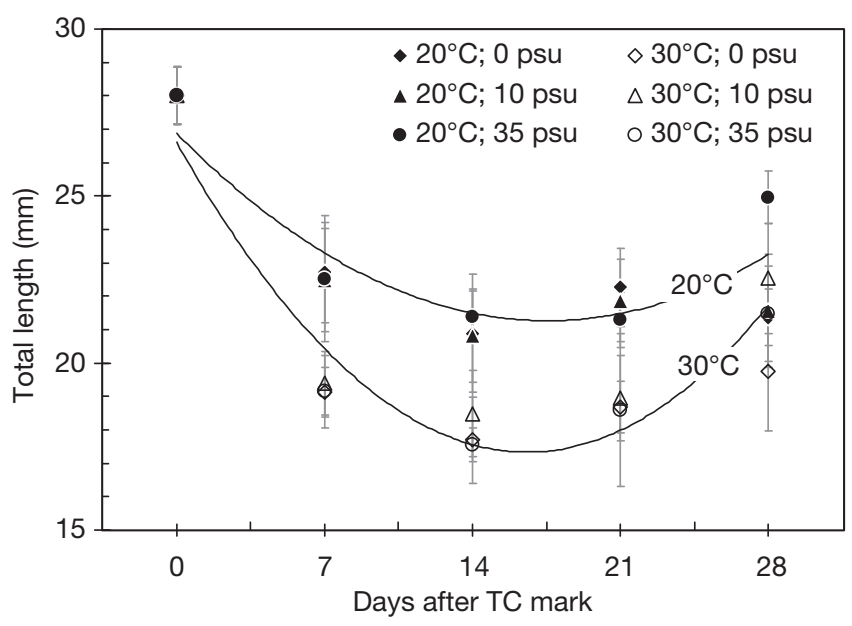

Fig. 4. Megalops cyprinoides. Comparison of the shrinkage in mean $( \pm \mathrm{SD})$ total length of Pacific tarpon leptocephali reared at 20 and $30^{\circ} \mathrm{C}$ in 3 different salinities $(0,10$ and $35 \mathrm{psu})$ for $1 \mathrm{mo}$ 

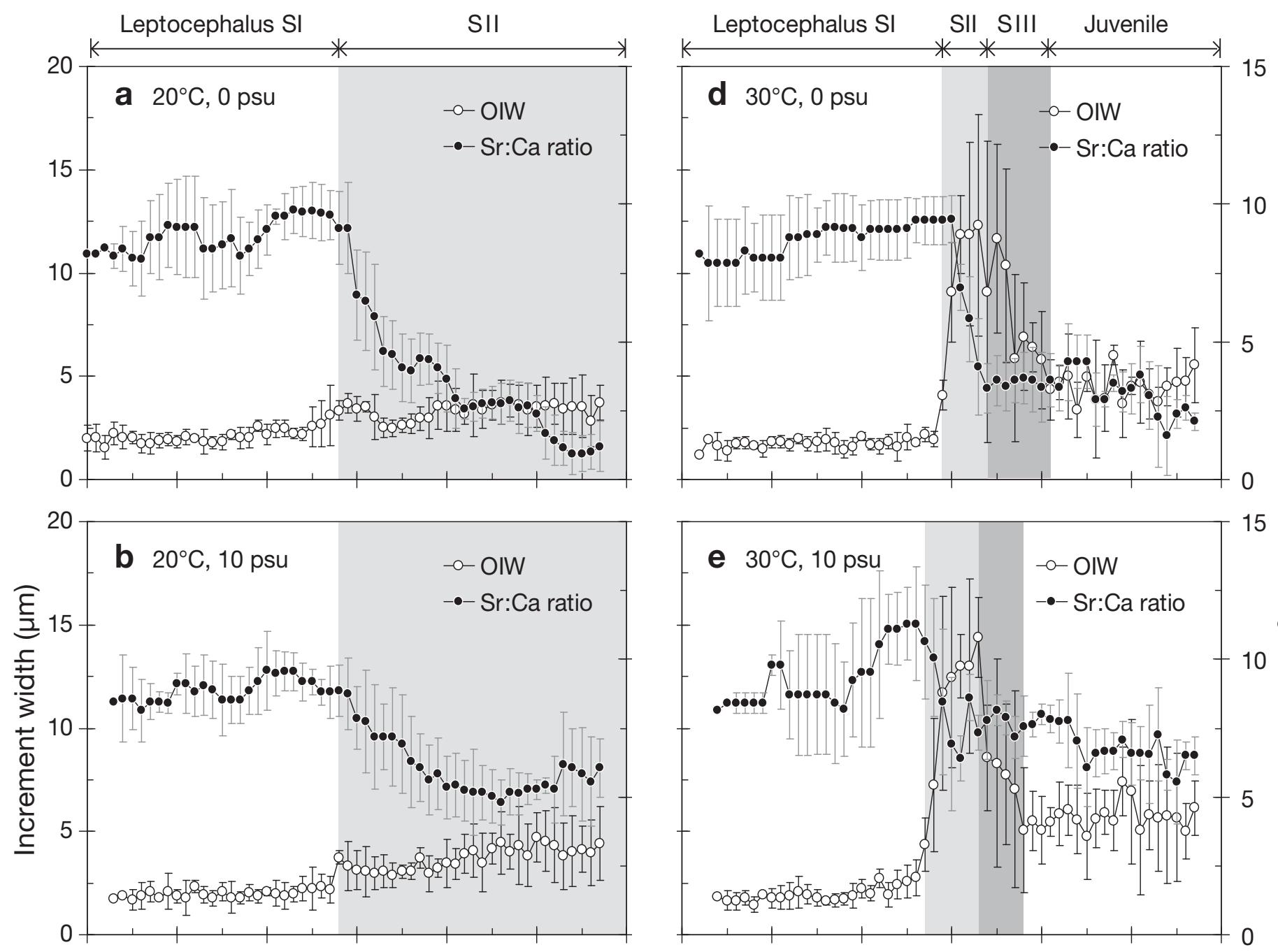

$15 \frac{15}{10}$
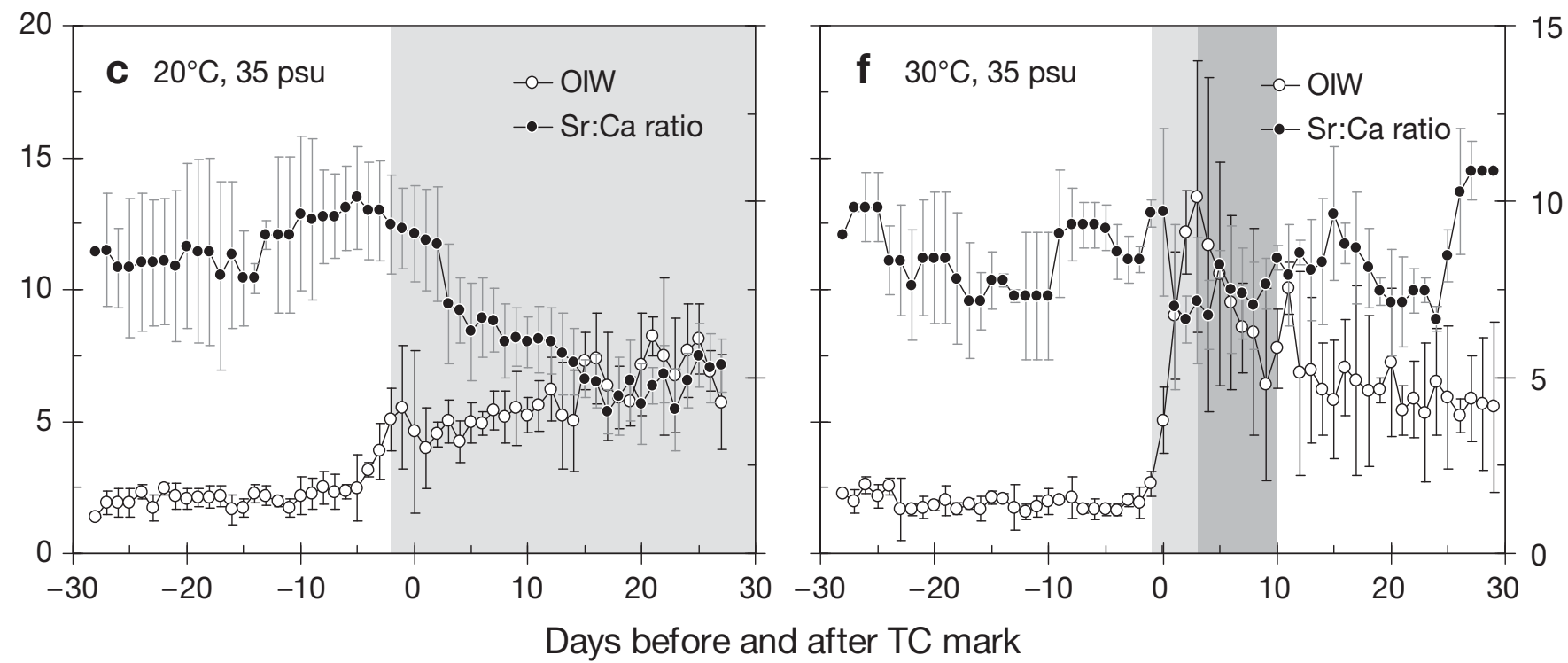

15

Days before and after TC mark

Fig. 5. Megalops cyprinoides. Temporal changes in mean $( \pm \mathrm{SD})$ increment width (OIW) and Sr:Ca ratios in otoliths of Pacific tarpon from the leptocephalus to juvenile stage in relation to temperature and salinity: (a) $20^{\circ} \mathrm{C}, 0 \mathrm{psu}$, (b) $20^{\circ} \mathrm{C}, 10 \mathrm{psu},(\mathrm{c}) 20^{\circ} \mathrm{C}$, $35 \mathrm{psu}$, (d) $30^{\circ} \mathrm{C}, 0 \mathrm{psu}$, (e) $30^{\circ} \mathrm{C}, 10 \mathrm{psu}$, (f) $30^{\circ} \mathrm{C}, 35 \mathrm{psu}$ 
The temporal changes in OIW and Sr:Ca ratios in otoliths of fish reared in a combination of 2 temperatures $\left(20\right.$ and $\left.30^{\circ} \mathrm{C}\right)$ and 3 salinities $(0,10$ and $35 \mathrm{psu})$ are shown in Fig. 5. The TC mark indicated that at the onset of the experiment the leptocephalus had entered SII for ca. 1 to $3 \mathrm{~d}$. At the leptocephalus SI, the mean OIWs were ca. $2 \mu \mathrm{m}$, but drastically increased to 12 to $14 \mu \mathrm{m}$ at the end of SII and subsequently decreased and fluctuated between 4 and $6 \mu \mathrm{m}$ from the end of SIII to the juvenile stage in the $30^{\circ} \mathrm{C}$ group (Fig. $5 \mathrm{~d}-\mathrm{f}$ ). However, in the $20^{\circ} \mathrm{C}$ group, OIWs slightly increased to only 4 to $7 \mu \mathrm{m}$, and larval metamorphosis was obviously delayed at SII (Fig. 5a-c). The effect of temperature on the ontogenetic shift rate was considerable. OIW was significantly affected by temperature ( $\mathrm{p}<$ 0.001 ) but not by salinity $(p=0.23$ ) at SII (but with interaction effect between salinity and feeding regime $\mathrm{p}<0.001$ ). At $30^{\circ} \mathrm{C}$, salinity had little effect on the OIW at SIII $(\mathrm{p}<0.05)$ but had a higher effect at the juvenile stage $(p<0.001)$.

On the other hand, the mean otolith $\mathrm{Sr}$ : Ca ratios of the $20^{\circ} \mathrm{C}$ group dramatically decreased from 8 to $10 \times$ $10^{-3}$ in SI to $<2 \times 10^{-3}$ in SII for the 0 psu group and to 4 to $6 \times 10^{-3}$ in the 10 and 35 psu groups (Fig. 5a-c). At $30^{\circ} \mathrm{C}$, the $\mathrm{Sr}$ : Ca ratios decreased to 2 to 4,6 to 8 , and 7 to $11 \times 10^{-3}$ for the 0,10 and 35 psu groups, respectively, after SII (Fig. 5d-f). The decrease in otolith $\mathrm{Sr}$ :Ca ratios was not significantly different between 20 and $30^{\circ} \mathrm{C}$ groups $(\mathrm{p}=0.13)$ but was significantly different among salinities $(0,10$ and 35 psu, p < 0.01). In SIII at $30^{\circ} \mathrm{C}$, the $\mathrm{Sr}$ :Ca ratios differed significantly among salinities $(p<0.001)$. The differences occurred between 0,10 and 35 psu (all p < 0.001) but not between 10 and $35 \mathrm{psu}(\mathrm{p}=0.84)$. In the juvenile stage at $30^{\circ} \mathrm{C}$, the $\mathrm{Sr}$ :Ca ratios also differed significantly among salinities $(p<0.001)$.

\section{DISCUSSION AND CONCLUSIONS}

\section{Factors affecting metamorphosis}

In general, the metamorphosis of fish occurs at the life-stage transition from the larval to the juvenile with accompanying changes in feeding habits and habitat use, niche shift and the ability to avoid predators (McCormick \& Makey 1997, Leis \& McCormick 2002). At normal condition, the Pacific tarpon leptocephali required ca. 2 wk to complete the metamorphic process. Metamorphosis is initiated by environmental cues (such as ontogenetic habitat shift) and endogenous factors (Pfeiler et al. 1990, Tsukamoto \& Okiyama 1997, Arai et al. 2001). All the leptocephali we caught in a low-salinity estuary started metamorphosis, even though they were subsequently transferred to $15 \mathrm{psu}$ for a $1 \mathrm{~d}$ acclimation before being transferred to experimental conditions of low or high salinity and temperature, and were fed or starved. Therefore, the low salinity in the estuary is probably a cue for initiating the metamorphosis of tarpon leptocephali. Pfeiler et al. (1990) also pointed out that contact with coastal water is one of the cues for metamorphosis of bonefish leptocephali. Arai et al. (2001), however, proposed that temperature change and growth rate may play an important role in the metamorphosis of Anguilla leptocephali. We have found that tarpon leptocephali at $20^{\circ} \mathrm{C}$ could not complete metamorphosis and stayed at SII, but the completion of SII needed only $7 \mathrm{~d}$ at $25^{\circ} \mathrm{C}$ and 3 to $4 \mathrm{~d}$ at $30^{\circ} \mathrm{C}$. This indicated that temperature is a principal promoter for the metamorphosis of the leptocephalus of Pacific tarpon.

In the present study, the fed leptocephali kept in a low-salinity environment had better somatic growth during metamorphosis. Fish living in lower salinities spend less energy for osmoregulation (Furspan et al. 1984, Boeuf \& Payan 2001) and therefore have more energy for somatic growth. Leptocephali that can feed have a better somatic and otolith growth rate than starved fish. This indicates that nutrition is important but is not necessary to ensure the metamorphic process because GAGs are stored as an energy source for the metamorphosis of most fish with a leptocephalus stage (Pfeiler 1986). On the other hand, the OIW of the leptocephali at SII increased in both low and high salinities and in both fed and starved conditions. This suggests that, whatever the level of external nutrition, endogenous energy has been used during fish metamorphosis, and this process may be under the control of thyroid hormones (Shiao \& Hwang 2006). Pfeiler (1997) found that bonefish leptocephali can survive for $10 \mathrm{~d}$ in a starved condition in artificial seawater during metamorphosis. Amara \& Galois (2004) also proved that the metamorphosis of sole was not affected by starvation, although the OIW was lower in starved than in fed larvae. The use of endogenous energy was also proposed for the carapid fish Campus homei (Parmentier et al. 2004). In the present study, we have found that Pacific tarpon can still undergo metamorphosis after starving for $18 \mathrm{~d}$. In other words, the metamorphosis of the leptocephalus cannot be stopped by starvation, although the metamorphosis rate slowed.

\section{Source of endogenous energy driving metamorphosis}

Extracellular GAGs are a gelatinous material that constitutes much of the leptocephalus body and function like stored polysaccharides, providing non-trophic endogenous energy for the metamorphosis from leptocephalus to juvenile (Pfeiler 1986). The stored energy 
of GAGs in the Pacific tarpon leptocephalus was released in SII, as reflected by faster otolith growth and wider OIWs, even in the starved group at normal temperatures. The OIW was also found to abruptly increase at the onset of the metamorphosis of the European conger eel Conger conger (Correia et al. 2006). The decreased OIW of the leptocephali at SIII in both fed and starved groups is indicative of an endogenous effect and is not correlated with environment salinity. The OIW, however, did not increase considerably in SII at winter temperature conditions $\left(20^{\circ} \mathrm{C}\right)$, and the leptocephalus did not develop to SIII. This indicated that lower temperature may retard the GAGs degradation and subsequently the metamorphosis process.

Each enzyme has its optimal temperature at which it functions rapidly. The enzyme activity for metamorphosis may be reduced at winter temperatures $\left(20^{\circ} \mathrm{C}\right)$ and thus the Pacific tarpon leptocephalus cannot metamorphose completely. Their total length shrank by $20 \%$, ca. $15 \%$ less than the normal shrinkage of the leptocephali at higher summer temperatures $\left(30^{\circ} \mathrm{C}\right)$ (Fig. 4). Their somatic tissue did not degrade completely, and less energy was released for both the metamorphosis process and otolith growth. Otoliths and bones have different calcification modes, but their growth depends on the calcium level of the fish plasma (Pannella 1980, Mugiya 1984). Moreover, a correlation between otolith formation and body (or skull) development is usually observed (Campana \& Jones 1992, Parmentier et al. 2001). However, some skeletal elements could also constitute a reusable $\mathrm{Ca}^{2+}$ stock. For example, resorption of larval teeth and of the gelatinous matrix (GAGs) in leptocephalus larvae releases $\mathrm{Ca}^{2+}$ that is used in the formation of the skeleton (Pfeiler 1997); the salmon Salmo salar undergoes demineralization of the vertebral column, the calcium of which is used for the remodeling of cranial bones for sexual maturation (Kacem et al. 2000). In Campus homei, the demineralization of the vertebral bodies could enhance calcium levels required for the formation of calcified structures (Parmentier et al. 2004). In other words, at low temperature, the energy released by body degradation during metamorphosis and the development of bones and otoliths, as indicated by body reduction, is decreased.

\section{Effects of salinity on otolith Sr:Ca ratios during metamorphosis}

Otolith Sr:Ca ratios are known to be related to ambient salinity. But during the metamorphosis of Pacific tarpon, the Sr:Ca ratios all suddenly decreased during SII at $25^{\circ} \mathrm{C}$ irrespective of the salinity at 10 or $35 \mathrm{psu}$ and being fed or starved. This suggests that the drastic decrease in otolith $\mathrm{Sr}$ :Ca ratios during metamorphosis is not due to the transition from the high salinity in the offshore to low salinity in the estuary, but due to an endogenous physiological effect. The otolith Sr:Ca ratios were higher in SI (the marine larval stage), but suddenly decreased in SII irrespective of salinity and feeding regimes, and remained stable in SIII at the same level as in SII. There was high, but decreasing, amplitude in SII in 0 psu than in 10 and 35 psu treatments. The similar decrease in amplitude of $\mathrm{Sr}: \mathrm{Ca}$ ratios suggests that SII might be a body remodeling stage. At this stage Sr:Ca ratios always decreased no matter what the salinity and feeding situations were. But salinity also had an additive effect in otolith $\mathrm{Sr}$ :Ca ratios. Leptocephali needed several days to finish the reconstruction and modification of their osmoregulation system after migrating from offshore to an estuarine environment. Otake et al. $(1994,1997)$ and Arai et al. (1999) found that the Sr:Ca ratios in the otoliths of Anguilliformes eels drastically decreased during metamorphosis, and they have proposed that this decrease is due to the degradation of matrix GAGs in the leptocephalus body during metamorphosis because GAGs are affinitive to cations (such as $\mathrm{Sr}$ and $\mathrm{Ca}$ ) and become Sr-rich sulphated GAGs. GAGs degrade during metamorphosis, which lead to a reduced ability to bind with $\mathrm{Sr}$, and subsequently the otolith $\mathrm{Sr}: \mathrm{Ca}$ ratio is drastically decreased.

The Sr:Ca ratios in Pacific tarpon otoliths after SII were significantly influenced by the ambient salinity under normal growth condition (with feeding and at higher temperature). The decrease, at $30^{\circ} \mathrm{C}$, in tarpon otolith Sr:Ca ratios after SII to 2 to $4 \times 10^{-3}$ in 0 psu and 6 to $8 \times 10^{-3}$ in 10 psu (but maintained at the same level in $35 \mathrm{psu}$ ) implies that the migratory environmental history of juvenile and adult Pacific tarpon can be reconstructed from the otolith $\mathrm{Sr}$ :Ca ratio profile, as it has been for many other teleost fishes (Secor et al. 1995, Tzeng et al. 2002). The otolith Sr:Ca ratio of Pacific tarpon after metamorphosis was also influenced by water temperature and diet, but we did not analyze this because the leptocephali died during metamorphosis due to starvation (Expt I) and low temperature $\left(20^{\circ} \mathrm{C}\right.$ in Expt II). Thus, data of otolith $\mathrm{Sr}$ :Ca ratios in the succeeding developmental stages were not available for comparison, although positively correlated (Elsdon \& Gillanders 2004), negatively correlated (Townsend et al. 1992) and uncorrelated (Gallahar \& Kingsford 1996) effects of temperature on otolith Sr:Ca ratios have been reported in other fishes. The negatively correlated effect of fish growth rate in the otolith $\mathrm{Sr}$ :Ca ratios has also been found in the white grunt Haemulon plumieri (Sadovy \& Severin 1992). We believe that temperature as well as feeding will influence the uptake of $\mathrm{Sr}$ and $\mathrm{Ca}$ in tarpon otoliths be- 
cause temperature has a significant influence on their ontogenetic shift and somatic growth rates (Farrell \& Campana 1996).

In conclusion, the present study demonstrated that once the Pacific tarpon leptocephalus starts metamorphosis, it is not affected by salinity and food but is significantly affected by temperature. The drastic decrease in $\mathrm{Sr}$ :Ca ratios during metamorphosis is affected by both ontogeny and salinity. Rapid otolith growth during metamorphosis is due to the release of large amounts of endogenous energy from the degradation of GAGs. Lower temperatures will delay metamorphosis. The Sr:Ca ratios in the otolith of the Pacific tarpon are positively related to ambient salinity after metamorphosis. These ontogenetic effects in the otolith Sr:Ca ratios should be taken into consideration when otolith $\mathrm{Sr}$ :Ca ratios are used as an indicator in studying the migratory environmental history of the Pacific tarpon.

Acknowledgements. The National Science Council, Republic of China (NSC-95-2313-B-002-016) financially supported the study. The authors are grateful to Dr. J. C. Shiao for sample collection and Mr. N. J. S. Leander and Mr. B. M. Jessop for comments on the early draft of the manuscript.

\section{LITERATURE CITED}

Amara R, Galois R (2004) Nutritional condition of metamorphosing sole: spatial and temporal analyses. J Fish Biol 64: $72-88$

Arai T, Otake T, Limbong D, Tsukamoto K (1999) Early life history and recruitment of the tropical eel, Anguilla bicolor pacifica, as revealed by otolith microstructure and microchemistry. Mar Biol 133:319-326

Arai T, Limbong D, Otake T, Tsukamoto K (2001) Recruitment mechanisms of tropical eels Anguilla spp. and implications for the evolution of oceanic migration in the genus Anguilla. Mar Ecol Prog Ser 216:253-264

Boeuf G, Payan P (2001) How should salinity influence fish growth? Comp Biochem Physiol C Toxicol Pharmacol 130: 411-423

Campana SE (1999) Chemistry and composition of fish otoliths: pathway, mechanisms and applications. Mar Ecol Prog Ser 188:263-297

Campana SE, Jones CM (1992) Analysis of otolith microstructure data. In: Stevenson DK, Campana SE (eds) Otolith microstructure examination analysis. Can Spec Pub Fish Aquat Sci 117:73-100

Campana SE, Neilson JD (1985) Microstructure of fish otoliths. Can J Fish Aquat Sci 42:1014-1032

Chen HL, Tzeng WN (2006) Daily growth increment formation in otoliths of Pacific tarpon Megalops cyprinoides during metamorphosis. Mar Ecol Prog Ser 312:255-263

Correia AT, Antunes C, Isidro EJ, Coimbra J (2003) Changes in otolith microstructure and microchemistry during the larval development of the European conger eel (Conger conger). Mar Biol 142:777-789

Correia AT, Able KW, Antunes C, Coimbra J (2004) Early life history of the American conger eel (Conger oceanicus) as revealed by otolith microstructure and microchemistry of metamorphosing leptocephali. Mar Biol 142:777-789

Correia AT, Antunes C, Wilson JM, Coimbra J (2006) An evaluation of the otolith characteristics of Conger conger during metamorphosis. J Fish Biol 68:99-119

> Degens ET, Deuser WG, Haedrich RL (1969) Molecular structure and composition of fish otoliths. Mar Biol 2: 105-113

Elsdon TS, Gillanders BM (2004) Fish otolith chemistry influenced by exposure to multiple environmental variables. J Exp Mar Biol Ecol 313:269-284

> Farrell J, Campana SE (1996) Regulation of calcium and strontium deposition on the otoliths of juvenile tilapia, Oreochromis niloticus. Comp Biochem Physiol Comp Physiol 115:103-109

Forey PL, Littlewood DTJ, Ritchie P, Meyer A (1996) Interrelationships of elopomorph fishes. In: Stiassny MLJ, Parenti LR, Johnson GD (eds) Interrelationships of fishes. Academic Press, New York, p 175-191

Furspan P, Prange HD, Greenwald L (1984) Energetics and osmoregulation in the catfish Ictalurus nebulosus and I. punctatus. Comp Biochem Physiol A 77:773-778

Gallahar NK, Kingsford MJ (1996) Factors influencing Sr/Ca ratios in otoliths of Girella elevata: an experimental investigation. J Fish Biol 48:174-186

$>$ Jessop BM, Shiao JC, Iizuka Y, Tzeng WN (2006) Migration of juvenile American eels Anguilla rostrata between freshwater and estuary, as revealed by otolith microchemistry. Mar Ecol Prog Ser 310:219-233

> Kacem A, Gustafsson S, Meunier FJ (2000) Demineralization of the vertebral skeleton in Atlantic salmon Salmo salar L. during spawning migration. Comp Biochem Physiol A 125:479-484

Kalish JM (1989) Otolith microchemistry: validation of the effects of physiology, age and environment on otolith composition. J Exp Mar Biol Ecol 132:151-178

Leis JM, McCormick MI (2002) The biology, behavior, and ecology of the pelagic, larval stage of coral reef fishes. In: Sale PF (ed) Coral reef fishes: new insights into their ecology. Academic Press, San Diego, CA, p 171-209

Ling YJ, Iizuka Y, Tzeng WN (2005) Decreased Sr/Ca ratios in the otoliths of two marine eels, Gymnothorax reticularis and Muraenesox cinereus, during metamorphosis. Mar Ecol Prog Ser 304:201-206

McCormick MI, Makey LJ (1997) Post-settlement transition in coral reef fishes: overlooked complexity in niche shifts. Mar Ecol Prog Ser 153:247-257

> Melancon S, Fryer BJ, Gagnon JE, Yang Z (2005) Effects of crystal structure on the uptake of metals by lake trout (Salvelinus namaycush) otoliths. Can J Fish Aquat Sci 62: 2609-2619

Mugiya Y (1984) Diurnal rhythm in otolith formation in the rainbow trout, Salmo gairdeni: seasonal reversal of the rhythm in relation to plasma calcium concentrations. Comp Biochem Physiol 78:289-293

- Otake T, Ishii T, Nakahara M, Nakamura R (1994) Drastic changes in otolith strontium/calcium ratios in leptocephali and glass eels of Japanese eel Anguilla japonica. Mar Ecol Prog Ser 112:189-193

Otake T, Ishii T, Nakahara M, Nakamura R (1997) Changes in otolith strontium:calcium ratios in metamorphosing Conger myriaster leptocephali. Mar Biol 128:565-572

Pannella G (1971) Fish otoliths: daily growth layers and periodical patterns. Science 173:1124-1127

Pannella G (1980) Growth pattern of fish sagittae. In: Rhoad DC, Lutz RA (eds) Skeletal growth of aquatic organisms: biological records of environmental change, Vol 1. Topics in geobiology. Plenum Press, New York, p 519-560 
Parmentier E, Vandewalle P, Lagardère F (2001) Morphoanatomy of the otic region in carapid fishes: eco-morphological study of their otoliths. J Fish Biol 58:1046-1061

Parmentier E, Lecchini D, Lagardère F, Vandewalle P (2004) Ontogenic and ecological control of metamorphosis onset in a carapid fish, Campus homei: experimental evidence from vertebra and otolith comparisons. J Exp Zool 301A: $617-628$

Pfeiler E (1986) Glycosaminoglycan breakdown during metamorphosis of larval bone fish Albula. Mar Biol Lett 5:241-249

Pfeiler E (1997) Effect of $\mathrm{Ca}^{2+}$ on survival and development of metamorphosing bonefish (Albula sp.) leptocephali. Mar Biol 127:571-578

Pfeiler E, Almada E, Vrijenhoek RC (1990) Ontogenetic changes in proteins and isozyme expression in larval and juvenile bonefish (Albula). J Exp Zool 254:248-255

Sadovy Y, Severin KP (1992) Trace elements in biogenic aragonite: correlation of body growth rate and strontium levels in the otoliths of the white grunt, Haemulon plumieri (Pisces: Haemulidae). Bull Mar Sci 50:237-257

Secor DH, Henderson-Arzapalo A, Piccoli PM (1995) Can otolith microchemistry chart patterns of migration and habitat utilization in anadromous fishes? J Exp Mar Biol Ecol 192:15-33

Shiao JC, Hwang PP (2006) Thyroid hormones are necessary for metamorphosis of tarpon Megalops cyprinoides leptocephali. J Exp Mar Biol Ecol 331:121-132

Townsend DW, Radtke RL, Corwin S, Libby DA (1992) Strontium/calcium ratios in juvenile Atlantic herring (Clupea harengus L.) otoliths as a function of temperature. J Exp Mar Biol Ecol 160:131-140

Tsukamoto K (1992) Discovery of the spawning area for

Editorial responsibility: Asbjørn Vøllestad,

Oslo, Norway
Japanese eel. Nature 356:789-791

Tsukamoto K, Arai T (2001) Facultative catadromy of the eel Anguilla japonica between freshwater and seawater habitats. Mar Ecol Prog Ser 220:265-276

Tsukamoto Y, Okiyama M (1997) Metamorphosis of the Pacific tarpon, Megalops cyprinoides (Elopiformes, Megalopidae) with remarks on development patterns in the Elomorpha. Bull Mar Sci 60:23-36

Tzeng WN (1996) Effects of salinity and ontogenetic movements on strontium:calcium ratios in the otoliths of the Japanese eel, Anguilla japonica. J Exp Mar Biol Ecol 199: 111-122

Tzeng WN, Yu SY (1986) Occurrence of the leptocephalus larvae of Elops hawaiensis and Megalops cyprinoides in the Gong-shy-tyan River estuary of north Taiwan with reference to some ecological and taxonomic aspects. Proc Symp Mar Biol Sci, Biology Research Center, Nat Sci Counc Monogr Ser 14:165-176

Tzeng WN, Yu SY (1992) Effects of starvation on the formation of daily growth increments in the otoliths of milkfish Chanos chanos (F.) larvae. J Fish Biol 40:39-48

Tzeng WN, Shiao JC, Iizuka Y (2002) Use of otolith Sr:Ca ratios to study the riverine migratory behaviors of Japanese eel Anguilla japonica. Mar Ecol Prog Ser 245:213-221

Tzeng WN, Shiao JC, Yamada Y, Oka HP (2003) Life history patterns of Japanese eel Anguilla japonica in Mikawa Bay, Japan. In: Dixon DA (ed) Biology, management, and protection of catadromous eels. Am Fish Soc Symp 33: 285-294

Tzeng WN, Chang CW, Wang CH, Shiao JC and others (2007) Misidentification of the migratory history of anguillid eels by Sr/Ca ratios of vaterite otoliths. Mar Ecol Prog Ser 348: 285-295

Submitted: October 22, 2007; Accepted: May 15, 2008 Proofs received from author(s): June 25, 2008 